ISSN 2077-1444

www.mdpi.com/journal/religions

Article

\title{
Notions of Female Authority in Modern Shi'i Thought
}

\author{
Mona Tajali \\ Department of Humanities, Concordia University, 1455 De Maisonneuve Blvd. W., Montreal, Quebec, \\ H3G 1M8, Canada; E-Mail: mtajali@alcor.concordia.ca; Tel.: +1-514-660-0920
}

Received: 22 August 2011; in revised form: 8 September 2011 / Accepted: 20 September 2011 / Published: 22 September 2011

\begin{abstract}
The dominant Shi'i gender discourse has undergone major shifts in recent years, resulting in revisions of various jurisprudential rulings on women's rights and status. Among such shifts, there have been rulings on female authority, particularly women's right to access political decision-making positions. Despite being a controversial topic that has historically faced much clerical debate and disagreement, in recent years a number of reformist clerics have argued in favor of women's leadership, which is considered a radical departure from the conventional stance. While there are a number of reasons that have contributed to these modernist clerical views in recent years, I argue that the most significant is women's demands and mobilization for reform of misogynist Shari'a-based laws. Through reference to clerical gender discourses unfolding in Iran, a Shi'i state, this work will shed light onto the modernist clerical discourses that resulted from women's strategic and organized pressuring for enhanced women's political representation. In this regard, this work will examine the interactions between women's groups and religious elites, in particular pious women's efforts to publicize and politicize the issue of female authority and women's access to leadership positions within the Iranian society, as well as the various types of justifications offered by Shi'i clerics for enhancing women's political rights. By analyzing the recent clerical reformist discourses, this article identifies two dominant types of justifications used by such clerics in explaining the shift from the conventional stand on the subject of female authority, which are categorized as a contextual rereading and a feminist rereading. This analysis will conclude by evaluating the impact of these different types of clerical responses on the future prospects of reform in the society, especially democratization of religious interpretation.
\end{abstract}

Keywords: female authority; Iran; political representation; reform; Shi'i Islam 


\section{Introduction}

Historically, Muslim jurists have never reached a consensus on the notion of female authority, understood as women's access to decision-making or leadership positions, ranging from judgeship to presidency or imamate. Within dominant Shi'i religious thought, the conventional stance has been that women are banned from positions of religious and political authority. This type of exclusion was often justified through clerical reference to Islamic texts which alluded to women's inferiority and incapability for leadership or judgeship positions. The majority of Shi'i scholars, similar to their Sunni counterparts, have historically emphasized women's roles within the private sphere, while considering the public or the political sphere as a male domain [1,2]. In the modern context, this clerical stance was further reinforced in the aftermath of the 1979 Islamic Revolution in Iran, which established a theocracy that brought prominent Shi'i clerics to power while also adopted various democratic features, resulting in an Islamic Republic. The Islamization that followed enacted policies that impacted women's rights, including hindering their access to key political decision-making positions. However, Iranian women have continuously challenged this traditionalist interpretation through women-centered rereading of religious texts; and have at times worked with in the limited democratic structures of the country to demand increased women's representation in politics. In recent times, women's demands for reform have resulted in more liberal and reformist interpretations concerning notions of female authority in which few religious leaders have shown an inclination to reconsider their traditionalist position. It is the purpose of this article to outline the major reasons that have contributed to these recent shifts, with particular emphasis on the role of women's strategic organizing towards addressing women's political underrepresentation, as well as the clerical responses to such mobilization. Hence, the key questions that this work will address are: Why is the issue of female authority increasingly becoming the subject of much clerical discourse (or what are the factors that encourage Shi'i clerics to address this issue in recent times)? What are the strategies of women's rights advocates to bring about such religious reforms? And what is the impact of these reforms on democratization of clerical interpretation of religious doctrines, particularly in the area of women's rights and status?

This article will address these questions through using Iran as a case study, since the country's transformation from a secular to a theocratic state as well as its more recent rise in religious reformism, provides us with a suitable instance to analyze and track the negotiations and interactions that occur between key actors concerning gender roles [3,4]. In my examination, I have divided this article into three parts. In the following section I provide a historical analysis of women's status and organizing since the Islamic Revolution. In the third section, through reviewing a number of primary sources, such as Iranian women's journals, organizational reports, clerical publications, and secondary sources, I will present a narrative of the various demands made by influential groups of Iranian women as well as their strategies for accessing political decision-making positions in recent years. This section draws attention to the main actors who campaigned for women's increased levels of political representation, while recognizing that their demands have evolved over the last three decades and have been raised by various groups and individuals who may not always see eye to eye. In these discussions, I particularly highlight the role played by a number of pious women's rights activists who publicized and promoted women's increased access to political positions using a religious discourse 
and demanded institutional reforms within the state structure. This section will be followed by an analysis of the modern Shi'i discourses on female authority through examining the discourses of two influential Iranian reformist clerics, and their impact on future gender discourses. In this regard, I will analyze the significance of the recent shifts in clerical attitudes concerning female authority given their impact on official state discourse on female authority, women's rights to access key political decisionmaking positions, as well as on overall religious reform and democratization of religious interpretation.

The central argument of this work is that the major shifts on notions of female authority in recent Iranian Shi'i thought have been the result of the discourses launched by feminists, proponents of gender equality, and various reformists. These demands, which took place in the public sphere, involved questioning the religious authorities who were occupying the top positions of the state pyramid, on their reasoning for denying women's access to positions of authority, and pressuring for reforms. Today, notions of female authority are hotly debated in the theocratic regime as various Iranian women's groups and movements, who are armed with modernist arguments as advanced by reformist or liberal clerics, continue to pressure both state and society for enhancement of women's political rights. Hence, women's actions and challenges have forced Shi'a clerics to respond and modify some aspects of classical Shi'i law that relate to women's leadership roles, though the clerical approaches to such reforms have differed in two central ways, namely, the contextual and feminist approaches of rereading of religious texts, as will be explained below. In this regard, I argue that women's activism has not only shed light onto the lack of consensus among religious leaders on this issue, but has also given rise to reformist discourses that enhance women's access to positions of authority. Such shifts, negotiations, and responses of the theocratic regime, deserve further scholarly attention, as they illustrate that Islamic jurisprudence on women's rights and status are not written in stone, and can be subject to internal criticism and eventual change, given effective pressuring and organizing (formally and informally) from key actors, particularly domestic women's movements [5]. I will end the article by evaluating the impact of the continuation of women's negotiations with the clerical authority on democratization of religious interpretation. I will point to a minority of reformist clerics who acknowledge that the conventional clerical stands regarding female authority were misinterpretations. This acknowledgement in turn limits the clerical monopoly over interpretation and enables for multiplicity of voices, including women's own voices.

\section{Women's Organizing in Post-Revolutionary Iran}

Women's political participation, understood as exercising the right to elect or be elected into a political position, as well as engaging in other activities that influence politics and its structures, is a significant aspect of women's public presence. Women's active participation in the political sphere as citizens enables them to voice their needs and demands and influence or shape their political realities. There is a direct linkage between women's access to the public sphere and their right to participate in politics, since for centuries women were barred (and continue to be barred in some states) from the right to vote as they were considered to be ignorant of the social realities of their times. The patriarchal state or its elites often justified the ban on women's right to vote by declaring that women are out of the public sphere, which in turn negatively impacts their knowledge of politics or the realities of their 
time [6,7]. Further, it was emphasized that the women's male guardians, such as their fathers and husbands, can voice their needs and demands by voting on their behalf. However, such justification lost ground as increasing amounts of women, beginning with those who were educated and knowledgeable of their political surroundings, pushed for the right to vote. In this sense, a gap was realized between women's capabilities and the laws of the patriarchal state. Gradually reforms were undertaken to increase women's status in the public sphere. However, this process is still evolving and to this day not complete.

Women's gross underrepresentation in politics is illustrated by the fact that although women constitute at least half of the world's population, they are currently represented by only about 19 percent of female parliamentarians worldwide [8]. Women's underrepresentation tends to be even more pronounced in Muslim-majority countries, in which on average women constitute roughly 12.5 percent of total parliamentarians [8]. Iran is no exception to this trend and despite having granted women the right to vote in 1963 , today women constitute only 2.8 percent of the total parliamentarians which is a drop from the 7 percent that was reached right before the 1979 Islamic Revolution. In addition to women's marginal presence in the national parliament, Iranian women have also faced limited access to other decision-making positions, ranging from the presidency, to ministerial positions, and even positions of judgeship [9]. For instance, Shirin Ebadi, the first Muslim woman to have received the Nobel Peace Prize, was stripped of her judgeship position after the revolution due to a conservative interpretation that declared women's judgeship as un-Islamic [10].

A majority of such limitations were put in place at the time of the drafting of the 1979 Iranian Constitution, which not only declared maleness as a prerequisite for various religious and political leadership positions (at times overtly), but also emphasized women's private roles as mothers and wives through adopting a notion of complementarity in gender rights and duties [11]. The discourse of complementarity between men and women was championed by Ayatollah Morteza Mutahhari, a key formulator of the Islamic regime's gender discourse. According to this view, women's and men's gender roles and duties are different (but complementary) as prescribed by "nature". Woman's primary role is to satisfy her domestic duties for which she is psychologically and physically built, while man's is to protect his family and society due to his rationality and strength [1]. Furthermore, threatening this balance of complementarity among sexes leads to chaos in the Islamic society. For instance, pressuring or encouraging women to enter the public sphere without first satisfying their divine duties of motherhood and wifehood, threatens the institution of family, and therefore the Islamic society as a whole, since the family is its basic unit [12]. Hence, other rulings of the Islamic regime that barred women's participation included limiting women's employment, and adopting policies of veiling and gender segregation within the public sphere $[13,14]$.

However, this conservative clerical stance ignored the historical instances of Muslim women in positions of religious and political authority [15], as well as the diversity of clerical views on women's rights and status. As the new Iranian constitution was being drafted in 1979, the most conservative clerical voices monopolized power in their own hands and as a result prioritized their interpretations concerning family and gender relations over more liberal ones. Ironically, while diversity and disagreement (ikhtilaf) among clerics was considered acceptable and even welcomed in a Muslim community, Iran's Islamization process in the aftermath of the revolution attempted to present a uniform clerical position through codification. This major shift particularly holds true regarding female 
authority. For instance, although prior to the revolution various Shi'i clerics supported female judgeship or even helped train female mujtahids, or Muslim jurists who are qualified to interpret the law through ijtihad or independent reasoning, such as Banu Amin Isfahani; immediately after the revolution, the dominant clerical position banned women from judgeship and discouraged them from reaching the authoritative level of ijtihad [16]. In fact, Ayatollah Khomeini, the founder of the Islamic Republic, declared that women cannot serve as judges in an attempt to highlight the conservative nature of the new theocratic regime and to depart from more liberal interpretations [17]. This ban served to curtail women's access to other positions of religious and political authority in early postrevolutionary Iran since it was often cited as a justification for declaring women unfit for decisionmaking or leadership positions in general [2].

Yet, despite the fact that the official gender discourse of the Islamic state rendered women to the private sphere and granted them a lower societal status, Iranian women, who had realized their political potential during the revolution, could not be easily marginalized. Indeed, according to various scholars women's political rights could not be revoked by the Islamic government due to women's mobilization during the revolution and their significance as a voting bloc for the new regime [14]. In this sense, even the conservative voices that often emphasized women's domestic duties over their public presence, realized the need to be legitimated by the large groups of mobilized and politically conscious women, many of whom had played a key role in overthrowing the monarchy. Hence, as an important political move, Ayatollah Khomeini, who was himself an outspoken critic of female suffrage when it was granted by the previous regime in 1963 by declaring it "un-Islamic," shifted his position in 1979 by supporting women's political rights [9,13]. In fact, he publicly encouraged women to participate in politics and vote for the Islamic regime, not because they have the right to, but because it is their duty as stated by Shari'a $[9,18]$. He further maintained that women could participate in politics by voting even without the permission of their husbands [1].

Therefore, Iranian women as important political actors refused to accept their exclusion from important positions within the public sphere, particularly given the regime's early promises of Islamic justice and equality $[19,20]$. Various women's groups and movements were organized across the political and ideological spectrum, and each began to develop strategies to bring questions of gender justice and equality into the public discourse. In particular, pious women, who were marginalized by the monarchy and later felt betrayed by the Islamic regime, began to equip themselves with the necessary tools to undermine patriarchal rulings and practices. The primary tools that assisted them in their efforts were diversity of opinions among clerics on women's issues (especially the liberal clerical views), women's high levels of education and political consciousness, as well as their access to key religious figures and institutions. After a decade of experiencing life under an Islamic regime, various groups of pious women began to protest what they felt were patriarchal misinterpretations of religious texts that denied them their legitimate Islamic rights. These organized groups' main strategy of pushing for reform was to publicize the contradictory views of the religious authorities in women's magazines and other media outlets, and in a way hold the ulema accountable to their earlier promises of Islamic justice.

Eventually a religious women's movement developed in Iran which consisted of various religious women's groups and organizations. A majority of the members of this movement were devout Muslims who supported the Islamic Republic (though to different degrees), and sought to advance 
women's rights through a religious, rather than secular, framework [20,21]. Interestingly, by the early1990s, even those women who had once subscribed to the notions of complementarity of rights at the time of the revolution began to seriously challenge them by arguing that there is no inherent or logical link between patriarchy and Islamic ideals [21,22]. Yet, instead of abandoning religion or the regime's revolutionary ideals, these women choose to work within the existing political structure by publicly pressuring the clerics to reform various legislations and practices which they felt were discriminatory. Throughout such pressuring and campaigns for reform, pious women particularly took advantage of the diversity of opinions among clerics and strategically publicized and emphasize the most liberal and women-friendly voices. These groups of women's rights activists and their interactions and negotiations with reformist and liberal minded clerics gave rise to "new religious thought" (nowandishi-ye dini), which sought to bridge the gap between religious and secular intellectuals by adopting a pragmatic and flexible approach towards religious doctrines on democracy, freedom and human rights. The central argument of new religious thinkers were that "human understanding of Islam is flexible in that Islam's tenets can be interpreted to encourage pluralism and democracy, and that Islam allows change in the face of time, space, and experience [22]." Pious women's journals, such as Zanan (women) and Payam-e Hajar (Hajar's message), provided these intellectuals with a platform to publicize their stands on gender roles and women's rights, including women's access to key political decision-making positions, an issue which become a central demand of the Iranian women's movement.

As a result, I argue that many pious women, particularly those who have been fervent supports of the Islamic regime and its ideals, have been at the forefront of opening avenues for women's political representation. This has been partly due to the fact that some of the members of the religious women's movement were themselves learned women from the seminaries or daughters and wives of influential clerical figures. This insider position not only provided these pious women with unique opportunities to access key positions or pressure influential individuals, but also legitimized their demands for gender equality and female authority in the eyes of the ruling elites as genuine rather than western inspired. Many of these women make their claims through religion by arguing that gender equality is inherent in Islam but denied to them by the patriarchal misinterpretations. Hence, in an effort to further empower themselves, many pious women in Iran have been advocating women-centered re-reading and reinterpretation of religious texts. Indeed, the number of women's religious training centers has spread in recent years, to the extent that from merely five after the revolution, today there are more than 270 schools across Iran, many of which train female theologians and mujtahids with the objective of guiding other women in the religious ideals and values of the Islamic state [16,23], and gaining religious authority.

While there are instances of reformist and women-friendly re-interpretations of religious texts throughout Islam's history, Iran's pious women's rights activists fuse their religiously inspired demands with the modernist discourses of social justice and human rights [21]. Concerning women's access to political leadership positions, the women-centered re-reading of religious texts and traditions involves revival of women's voices and activities in early Islam that were lost through patriarchal interpretations and cultural influence. In this regard, the re-interpreters emphasize a number of instances of early Muslim women who were active in some way in the public sphere, or the Qura'nic verses that establish gender equality. Such instances include the important roles that Aisha, Fatima or 
Zeinab (the Prophet's relatives) played in early Islam as public figures, speakers, fighters, hadith transmitters, and Quran interpreters [24,25]; as well as a number of Qura'nic verses that tell the story of the successful Queen of Sheeba (Bilqis) or emphasize gender equality. Significantly, the Qur'an's account of Queen of Sheeba, the only queen mentioned in the Qur'an, tells the story of a thoughtful and just leader, who after consulting with her counsel makes the rightful decision of meeting with King Solomon and accepting to worship his creator, Allah [26].

To better illustrate the actions and strategies of pious women's rights advocates and religious reformists, I will outline their campaigns and efforts for enhancing women's access to different positions of authority within the Iranian state structure, namely the office of the presidency, ministerial positions, and the Council of Experts, a body which requires its members to have high levels of religious authority. Lastly, I will discuss the reformist clerical voices that have emerged due to women's campaigning and activism, particularly the two dominant reformist approaches of justifying women's access to positions of authority.

\section{Iranian Women's Demands and Strategies for Accessing Political Decision-Making Positions}

Among the first areas that women protested having limited access to, was the presidency. Although Iranian women considered having a share in decision-making to be one of their legitimate claims given their activism during the revolution, the formulators of the new constitution thought otherwise. In accordance with their traditional interpretations of religious doctrines that prioritized women's domestic roles, the majority male drafters of the 1979 constitution (only one female member, Monireh Gorji, was present among a total of 73 members), advocated entering a requirement of maleness for the position of the president in article 115 of the new Iranian constitution [14]. This move however faced the opposition of a number of drafters who advocated replacing the requirement for "maleness" with the more ambiguous term of "rijal," which can be understood either as "men" or as a gender neutral term of "personalities". The term rijal technically means men but according to its Arabic usage can also be granted to women as honorary men, or in the sense that women can advance to the extent that they become like men. This strategic compromise was made in response to the threat of protest of Iranian women's movement (including many Islamist women) that opposed inclusion of the prerequisite of maleness for the office of presidency [27]. The ambiguity of this term went unchallenged for almost two decades until 1997, when eight women, including Azam Taleghani, daughter of Ayatollah Mohammad Taleghani, announced their intention to campaign for the highest executive office. Azam Taleghani as a former member of the Iranian parliament (who had received among the highest percentage of popular votes ever casted for a parliamentarian) and a learned woman who was educated in religious seminaries [28], ran for this office in an attempt to challenge the ambiguous term of "rijal" in the Iranian constitution. As she later publicized in her journal, Payam-e Hajar, Taleghani sought the clarification of this contentious term from the Council of Guardians, a body that vets the qualification of registered candidates for most popular elections and consists of six clerics and six jurists [29].

However, Azam Taleghani's strategic registration of her candidacy in 1997 did not result in a clarification from the Council, who in the end disqualified all of the female candidates, but without mentioning their gender as a reason for their disqualification. In fact, the Council of Guardians 
disqualifies the candidacy of many applicants, regardless of gender, without providing any explanations for its decisions, despite a demand from various moderate politicians that the Council give legal reason for disqualification of candidates. The Council has rejected the requirement to provide written explanations for disqualified candidates by arguing that it is against religious law and might harm a person's reputation or threaten national security [30]. This aspect of the Council's functioning has been challenged and declared undemocratic since even incumbents or those whose candidacy was approved in previous elections can also be disqualified by the Council without an explanation, and hence unable to appeal the decision [30]. However, it can be argued that the Council is unlikely to approve the qualification of female candidates due to its conservative tendency. In response to such silence, Taleghani made yet another bold move to continue her pressure for reforms. Following her disqualification she took it upon herself to interview a number of Shi'i clerics on their opinions concerning female political authority as well as their interpretation of the term "rijal" as it appears in the constitution as a requirement for presidency. She then published these interviews in her journal Payam-e Hajar, in an effort to bring this debate into the public sphere and in turn increase the pressure on Iran's political and religious elites. By outlining the contradictory clerical views on the notion of female authority in Shi'i Islam, Taleghani successfully illustrated the lack of consensus that exists among Iran's religious leaders, while also emphasizing her own stance (as a learned Muslim woman) that there is no contradiction between women's political leadership and Islam [29].

This move encouraged more female presidential candidates to register in future elections since they understood the Council's silence on the issue of their gender as reason to further challenge male political hierarchy. Consequently, from merely eight, the number of women aspiring for presidential candidacy rose drastically to 47 and 89 for the 2001 and 2005 election years respectively, but fell to 42 for the 2009 elections [31-33]. At all of these elections, the Council never approved a single female candidate, despite their religious and political qualifications, while it never referred to the candidate's gender as a reason for the disqualification. Different groups of Iranian women, particularly those who had links to the Islamic regime, did not merely tolerate these extensive disqualifications and further pressured the Council, as well as other clerical elites, to clarify their interpretation of the term "rijal", mostly through women's journals. It was not until the 2009 presidential elections, that the Council for the first time declared that it interpreted this qualification in gender neutral terms, and it vetted the candidates merely based on their qualifications. When Abass-Ali Kadkhodayi, the spokesman for the Council of Guardians, was asked in a press conference shortly before the 2009 elections about whether there have been any changes on the Council's interpretation of the term "rijal" in its consideration of female candidates, he responded by staying that:

"The Council (itself) has never interpreted the term "political rijal". All that has thus far been mentioned (about this issue) has been from the media and legal bodies. The stance of the Council of Guardians has not changed. In the past female candidates registered to run for president as there is no specific limitation on the matter... The Council of Guardians has never arrived at its position based on an individual's gender, and whenever a woman was not qualified (to become a presidential candidate) it was because she lacked the necessary qualifications [34,35]."

This statement was yet another example of a major shift in the discourse of the regime on the topic of female authority, since in the previous presidential elections of 2005, the then spokesman of the 
Council, Gholam-Hossein Elham, clarified that the Council interpreted the term rijal in its literal meaning that is the male gender [35]. Nonetheless, Kadkhodayi's words in 2009, which came less than a month before the five-day candidate registration period, were widely publicized by different women's groups as they believed the current spokesman's words removed an institutional hindrance, at least in intention. This shift in the Council's rhetoric can partly also explain the drop in the number of registered female presidential hopefuls from 89 in 2005 to only 42 in 2009, as some women's groups considered it a victory and saw no need to further register as a pressuring strategy. On the other hand, other groups argued that had the Council once again defined the term rijal in gender-specific terms, it would have provided women with an opportunity to further dispute this stance in public. Yet despite these developments, key pious women's rights advocates continue to pressure and lobby for the approval of female candidates for the presidency, as many consider that actions of the Council speaks much louder than mere statements or press releases. For instance, Mrs. Touran Valimorad, the Secretary of Coalition of Islamic Women, considers the statements of the Council's spokesman as inadequate and states that, "rather than the spokesperson making these remarks, the Council should officially declare that women are able to become presidential hopefuls and act accordingly." [44].

Nevertheless, the Council of Guardian's eventual clarification of this contentious term demonstrates the extent of women's strategic efforts and pressuring on state elites, as well as some of the pressuring and negotiations that occurred between the religious women's groups and various reformist clerical figures. As will be illustrated in the following section, the reformist clerical voices have been playing a key role in assisting women's efforts to enhance their access to key political decision-making positions. Pious women's rights activists tactfully publicized the negotiations between clerics and women's demands in women's journals, which in effect provided a public platform for reformist clerics who favored reform of Islamic rulings that barred women's participation. In this regard, a number of liberal-minded clerics challenged the traditional rulings on female authority, and instead advocated reform in terms of modern contexts and women's realities. I argue that such pressures from below not only led to the popularization of the issue of female authority, but also to the eventual rise of various reformist clerical voices that approved women's access to political decision-making positions.

The late-1990s witnessed increased organizing on different levels concerning women's status within an Islamic society. Different Iranian women's groups and organizations, religious and secular alike, continued to strategize to enhance women's access to additional political decision-making positions other than the presidency, including ministerial positions. A significant political opportunity that presented itself for increasing women's political presence was the election of reformist President Khatami in 1997, who won with a landslide in a large part due to women's vote [17,36]. Khatami, himself a cleric, recognized many of women's demands and effectively mobilized their support by integrating them into his campaign promises. Among such promises were women's demands for increased representation in key political positions. Indeed, one of his publicized beliefs was that "the Islamic system and community should confidently appoint women to sensitive posts ... Limitations should not come in the way of broad participation by women in management, politics and society" (quoted in [36]). Many women along with other reformists were hopeful that Khatami would nominate women for ministerial positions. In fact, "one hundred sixty-three reformist members of the Sixth parliament signed an official letter expressing this expectation" [37]. 
However, despite these promises and women's expectations for increased levels for women's political representation during his presidency, particularly appointment of at least a female minister, Khatami, similar to the regime's former presidents did not appoint any female ministers to either one of his cabinets in 1997 or 2001. His only notable move was to include two women in his cabinet, and appointed Masumeh Ebtekar as the Vice President on environment and women's issues, and Zahra Shojai as his advisor and director of the Center for Women's Participation, which is part of the President's office. Once again, pious women's rights activists did not remain silent in the face of this defeat, and in response held a press conference with Khatami and the women in his cabinet, demanding an explanation from him for not appointing a single female minister despite being provided with lists from religious women's groups and organizations of qualified women's names that can serve as ministers. Similar, to Taleghani's tactic of publicizing the elites' responses, these women's rights activists also printed Khatami's responses in a women's journal (Zanan) after questioning him on this issue. To women's great dismay, Khatami is quoted as saying "selection of a female minister is not necessary, and I couldn't risk appointing a woman as minister" [38]. He further used the neotraditionalist rhetoric of meritocracy (Shayestegrayee), by emphasizing women's qualities for political office over all else, and argued that there is a lack of qualified female candidates for these posts. In the same interview, Khatami credited himself as being the only president of the Islamic Republic who has included women in his cabinet, by stating that "position of a vice president is similar to being a minister, with the difference that she is not subject to Parliament's questioning on her performance, rather the president is questioned" [38]. The journal also presented key women's responses to Khatami's comments, including Jamileh Kadivar, a female parliamentarian who received the second highest percentage of popular votes in her constituency. Kadivar raises issue with Khatami's equation of selecting female ministers to a political "risk," by emphasizing that we cannot reform our society without first reforming our discriminatory practices [38].

Recognizing themselves as political agents, women did not cease their efforts for further reforms even with the reformist loss in the 2005 elections that brought conservative President Ahmadinejad to power. In fact, women's pressures intensified with every presidential election, and their strategic organizing led to creation of a coalition prior to the 2009 presidential elections that brought together many women's groups and individual activists across a wide spectrum, ranging from secular and liberal to religious and conservative women [37]. This coalition, called the Convergence of Women (hamgarayee zanan), played a key role in pressuring the presidential candidates to announce their plans for the advancement of Iranian women's status, while also unifying women's voices in terms of their demands and expectations from the new administration.

Ironically, the first ever nomination of female ministers in the history of the Islamic Republic did not come from a reformist president, but from Ahmadinejad, who in his second term in 2009 nominated three women for parliament's approval as ministers of health, social welfare and education. In the end, the parliament approved the nomination of only one of the female nominees with 175 votes from a total of 286, and Ms. Marzieh Vahid Dastjerdi became the minister of health. This success is primarily credited to the pressuring and lobbying efforts of a conservative religious women's organization called Zeinab Society, which provided Ahmadinejad with a list of names of potential women for ministerial positions, among which was Vahid Dastjerdi's name [37]. 
However, this approval was not without controversy, as Ahmadenejad's nomination of female candidates faced opposition from many conservative clerics, and amplified the division among Iran's clerics. Conservatives responded negatively to the "innovative idea to choose women as ministers" by emphasizing that there are "religious uncertainties" about women in managerial positions [39]. Also when Ahmadinejad attempted to fill the remaining empty ministerial positions with two other female candidates, the head of the Parliament's Clerics' Faction, Mohammad-Taqi Rahbar, responded that "as a number of ulema oppose nomination of women for post of minister, I believe that the administration should not insist on the issue" [40]. He further stated that the parliament approved the nominee for the ministry of health "because it wanted to meet the president's goal to have a women minister in his cabinet" [40]. This particular response of Rahbar was to downplay the female minister's qualifications for the post, which included decades of political experience as well as serving on managerial boards of medical associations and hospitals, by suggesting that the Parliament in fact did the president a favor by confirming Vahid Dastjerdi. Such reactions resulted in both women withdrawing their names from consideration so as not to offend the conservative clerics, despite their long history of political activism in conservative camps [37]. For instance, Fatemeh Alia who was nominated in the second round of parliamentary consideration by Ahmadinejad for Iran's education minister had more than 20 years of experience in education, and was a conservative member of the parliament [40].

The nomination and approval of a female minister had significant implications for notions of female authority in contemporary Shi'i thought, Iranian factional politics, and women's organizing tactics. This process, by involving clerics, various women's groups, as well as political elites, once again initiated a discussion on whether women should have access to political decision-making positions. The most significant gain from this process for women's groups was a 'green light' that they received concerning women's political authority from the highest religious authority in Iran, the Supreme Leader. This victory came about when high ranking women of the Islamic regime strategically sought the approval of Ayatollah Khamenei, on the subject of women ministers. Hence, despite massive pressures from conservative clerics on Marzieh Vahid Dastjerdi to resign her candidacy, Zeinab Society's director, Maryam Behroozi, lobbied Ayatollah Khamenei's office as well as his key supporters on supporting Dastjerdi's access to this powerful position, including a coalition of fourteen conservative groups titled the Front of the Followers of the Imam and the (Supreme) Leader [44,45]. After such lobbying campaigns, various conservative women officials publicized the favorable comments of the Leader on the subject matter [37].

In addition, once Dastjerdi's nomination for the post of health minister was finally approved by the parliament, instead of simply accepting it, she herself also paid a visit to Ayatollah Khamenei's office to ensure that he had not issued any statements against the appointment of female ministers. Once she received his blessing in this private meeting, Dastjerdi along with other religious women's groups, decided to publicize it in order to undermine the clerical forces that oppose women's political leadership, and in a way put an end to the clerical debates on this issue [37]. Needless to say, Khamenei's approval has been a significant shift in Shi'i political thought concerning female political authority and is regarded by many Iranian women as to have increased women's access to other important political decision-making positions, despite dispersed clerical opposition. This shift is even more significant given Khamenei's conservatism, and is a measure of pious women's influence and clout over even conservative political factions in addition to reformists; and is an indication of the 
extent that even the supreme leader depends on public legitimacy. Additionally, Ahmadinejad's radical move of nominating female ministers illustrates that male politicians and parties, regardless of political ideology, can no longer afford to ignore women as a political constituency, even in Iran's limited democratic structure [41]. In fact, Ahmadinejad strategically reacted to women's groups and their organizing efforts by nominating women for minister positions to not only gain women's support in the aftermath of the 2009 disputed presidential elections, but to also establish his independence from various conservative clerical factions [37]. In this regard, the process of appointment of female ministers involved strategic interactions between women's groups and political elites such as Ahmadinejad, both of whom took such political actions to further their interests.

Therefore, as illustrated, women's efforts for accessing political decision-making positions in the Islamic Republic have been effective since they often used their limited political rights to pressure the elites to react receptively to their demands. Indeed, 2009 witnessed two significant victories for Iranian women concerning female political authority. First was that the conservative Council of Guardians interpreted the term "rijal" in a gender neutral manner for the first time since the regime's foundation, and in turn gave its approval of women's candidacy for the presidency at least in rhetoric. Second, regardless of Ahmadinejad's motives, a woman was eventually appointed as a minister with the approval of the Supreme Leader, which will undoubtedly enhance women's access to other positions of authority.

While women's activism mostly surrounded increasing their access to positions of political authority, Zeinab Society, as a powerful religious women's group, also made the bold move of demanding women's enhanced access to positions of religious authority. Zeinab Soceity, which also functions as a conservative women's political party and oversees eight religious seminaries and Qur'an centers, nominated six female mujtahids in 2007 for the historically clerical (and all-male) Assembly of Experts [19]. According to law, this 86-member body must be composed of mujtahids who are elected popularly for eight-year terms, and are charged with electing or removing the Supreme Leader and supervising his activities. Therefore, although maleness is not mentioned as one of the requirements for the assembly's "experts," women are assumed to be automatically disqualified as there is a lack of consensus among the ulema on whether women can become mujtahids; though a majority believe that while a woman can reach this level of knowledge, she can only guide herself or be emulated only by other women. However, to the Zeinab Society's disappointment, the Council of Guardians, which also vets the candidates for election to this body, did not approve the candidacy of any of the six female mujtahids, all of whom were considered qualified by the Society. Although, the Council of Guardians once again did not provide an explanation for rejecting these women, the Society's nomination was nonetheless an important move to break the taboo that women cannot become religious leaders [19].

\section{Modern Shi'i Discourses on Female Authority}

As the above section illustrated, although Iranian women have been historically marginalized from the political sphere by facing various institutional and religious obstacles, they nonetheless consider their access to political decision-making as an important channel through which to influence politics and eventually advance their status. Women from across the ideological spectrum continuously 
pressured for increased levels of women's representation in different governmental positions, though in the end the religious women's groups, such as Zeinab Society, were more successful in attaining their goals, given Iran's theocratic political framework and women's own levels of religiosity and strategic organizing. However, an additional important aspect of the Iranian women's success was the support that they received from reformist or liberal clerics who provided them with modernist arguments in favor of female authority in political and at times religious fields. This support was provided to women as many religious clerics and political elites realized that they depend on women's legitimacy to stay in power. Such arguments, some of which were articulated by the highest ranking Shi'i clerics, not only legitimized women's demands but also illustrated that Islamic rulings concerning women's societal status are changeable according to modern times and contexts. Thus, as a result of women's strategic publicizing of such liberal clerical interpretations in the Islamic society, we are witnessing significant shifts concerning women's access to positions of authority, particularly since the early years of the revolution in which women were generally considered unfit to rule. Today, increasing amounts of clerics consider women's political participation and representation to be compatible with Islam, an argument which also resonates with the public.

However, the reformist interpretations that have been on the rise in recent years are dissimilar in their reasoning or justifications that they provide for departing from the conventional stance concerning female authority. I argue that it is now necessary for us to evaluate the impact of these reformist voices and their subtle varieties on democratization initiatives of religious interpretations, which have also been a central demand of many rights activists and religious intellectuals. Hence, aside from reforming rulings that barred women's participation, it is important to also examine the extent that Iranian reformist clerics are opening the gate for women's own interpretation of religious texts by taking into account their own qualifications and experiences. In this section, I will present the modern Shi'i discourses on female authority by referencing a number of clerics who addressed this issue, and conclude by analyzing the impact of such reformist clerical voices on future rights discourse developments and democratization of religious interpretation. This analysis is even more significant regarding Iran's gender discourse, since within the country's theocratic structure religious figures are often also political figures.

I argue that among the reformist voices, the clerical justification used for the modern shifts from the conventional stand falls into two dominant categories. In other words, reformist clerics justify their liberal interpretations concerning female authority according to two types of reasoning, each of which has a different implication for women and the future prospects of reform in the society. The first category which is contextual rereading refers to those Shi'i reformists who justify the shift on female authority through emphasizing contextual and environmental changes. In this regard, they argue that the "quality of women" has improved over time, providing them with the necessary skills or knowledge to acquire political or religious authority. On the other hand, a group of reformists argue that a feminist rereading of the texts is required to correct the conventional position. According to this view, previous marginalization of women from the political field was a clerical misinterpretation as it ignored the inherent egalitarian message of the Quran. Feminist rereading as initially advocated by Islamic feminists, and various scholars such as Riffat Hassan, Asma Barlas, Amina Wadud, and Fatima Mernissi, is increasingly gaining ground with a number of such reformists, mostly due to the pressures from the domestic women's movements. Despite writing from within the Sunni tradition, 
many of these scholars have had major transnational impact on reinterpretation of Islamic rulings on gender. In fact, transnational exchanges between Muslim communities have played a key role in the spread and authenticity of feminist inspired reinterpretations of Islamic texts. In this regard, feminist rereading in Iran cannot be isolated from the larger reformist developments across the Muslim world, which further geared Iranian reformists with religiously inspired arguments for gender equality.

It is important to note that many Shi'i reformists in Iran use a combination of both contextual and feminist rereading as justifications for the recent shifts in support of female authority, often by crediting these ideological shifts to women's own improvement while acknowledging the patriarchal cultural dominance that also negatively impacted women's political participation. To better illustrate each of these different reformist stands as well as their impact on modern Shi' $i$ thought on female authority I will refer to two popular clerical voices in Iran, namely the rhetoric of former Iranian president and mid-ranking cleric Mohammad Khatami, and Ayatollah Yousef Sanei, a renowned Shi'i marja, which is the highest level of religious authority in Shi'i Islam. Although both of these clerical figures are considered modernists with liberal notions on female authority, they depart on their justifications for the shift in ideology on enhancing women's access to political office. It can be argued that the different discourses and language used by these two particular figures reflect their different positions within the religious hierarchy and state structure. For instance, Sanei as a marja, has the authority to change classical rulings, whereas Khatami, as a lower ranking cleric lacks this authority in religious terms, and faced many limitations as a president since he was expected to work within the structures of power. Nonetheless, despite these positional differences which undoubtedly influences their discourses on female authority, my intentions are to draw attention to the impact of their justifications for reform on the public sphere's discussions concerning this issue as well as future democratization of religious interpretation. In other words, I argue that the justifications used by both Khatami and Sanei have a great impact on the gender discourses of the Islamic republic as well as on Iranian women and activists who are in search of effective and lasting solutions in addressing women's political underrepresentation. In this regard, it is also important to keep in mind that even these reformist clerics may shift in their ideologies, sometimes becoming more liberal.

Mohammad Khatami as an influential figure who emerged as the leader of the Iranian reform movement had various opportunities to advance women's levels of authority in politics, such as through nominating women to his cabinet or increasing women's candidacy for parliamentary reformist party lists. However, he failed to sufficiently address women's political underrepresentation during his presidency. As mentioned above, Khatami believes that "leadership posts in an Islamic society must be granted based on one's merit rather than gender" [29]. The rhetoric of meritocracy blames women's low levels of political representation on women's own lack of qualifications, which are gradually changing in modern Iran, particularly due to women's increasing levels of professionalism and activism. Therefore, according to this view contextual shifts such as women's own advancements led to women gaining the necessary qualifications for political office.

This viewpoint has various significant implications on the more general aspect of religious interpretations and women's societal and legal advancement. The major negative implication of this position is that it does not contribute to democratization of religious interpretation since it merely accommodates the gender perspective of the society without fundamentally altering the conventional interpretational framework. This reformist position maintains the clerical establishment's authority 
over declaring women's capabilities for leadership by placing the blame for women's historical lack of power on women themselves. Hence, it justifies women's access to authority in modern times through women's own progress rather than clerical misinterpretations. In other words, this view assumes that clerical interpretations that previously considered women as incapable or unqualified for political office were correct in their positions, since women themselves lacked these qualities. Such assumptive approach places little emphasis on the negative role of culture and various barriers deliberately and by design placed on women's access to politics, as well as the ever-changing nature of cultures. This position also ignores the factors that allowed men to reach the necessary qualifications in comparison to women.

On the other hand, a feminist re-reading which has been articulated by a number of Iranian reformists, hold that various patriarchal rulings on women were based on erroneous traditions (sonathaye qalat) in which cultural understandings of a particular time were mistakenly interpreted by clerics as universal religious mandates. One such cleric is Ayatollah Yousef Saanei, who publicly declares that "women are capable of being the Wali al-Faqih (guardian jurist) and that they could lead the prayers while the men pray behind them [42]." To this extent, Saanei has also produced a scholarly book at the Hawza al Illmiya (religious seminary) in Qom on women's jurisprudence, which further states that women can hold the office of president, and calls on his other colleagues, Sunni and Shi'a to act in accordance. This outspoken cleric on women's rights explains his position through reinterpreting Qur'anic verses and ahadith (sayings and deeds of the Prophet and Shi'i Imams) that were conventionally used to justify a ban on women's political or religious authority, rather than emphasizing women's qualifications in today's context. For instance, perhaps the most commonly cited argument against female authority is verse 4:34 of the Quran, which according to a traditional interpretation it considers men as guardians (quwwamuna) of women (or have authority over them) since God has favored one over the other. However, a modernist and feminist interpretation of this verse, as presented by Saanei, interprets this term as women's "maintainers," since men are entrusted with the financial responsibility to maintain their wives during marriage. This line of interpretation is justified since establishing male superiority over women goes against other Qur'anic verses that emphasize gender equality in all aspects of behavior [43]. Two examples of such verses are 3:195 and 33:35, both of which emphasize the spiritual equality between genders by stating that men and women will be rewarded and punished equally based solely on their actions.

Similar to questioning such patriarchal interpretations that go against the inherent egalitarian message of the Qur'an, feminist-centered interpreters also challenge the ahadith that are used to ban women's access to positions of leadership. For instance, the ahadith that consider women incapable of leadership by declaring them emotional rather than rational, physically and psychologically weak, bad managers, unintelligent, selfish, traitorous, and much more, are challenged primarily because they oppose Qur'an's message of gender equality. Other Shi'i scholars declare many of these ahadith as weak, inapplicable to Shi'i school of thought as they only exist in Sunni sources, or that they refer to only specific cases of female leadership (from particular contexts), and should not be considered as universal Islamic rulings on female authority, applicable for all times and contexts $[3,43]$.

This position departs from the contextual re-reading as it does not emphasize women's lack of qualifications, but rather puts the blame on clerical misinterpretations that declared women unfit to rule. Hence, this stance, as articulated by reformists such as Yusuf Saanei, Mehdi Mehrizi and Salehi 
Najaf Abady, emphasize clerical misinterpretations that unjustly hinder women's access to positions of power and ignored religious principles of gender equality. The implication of this latter stance is that by merely acknowledging clerical misinterpretation in the past, it undermines the clerical legitimacy and authority over interpretations and in a way democratizes religious interpretation. Such democratization is significant in terms of future interpretations and legal shifts that will unfold in the Iranian context, as it acknowledges the ulema's possibilities for error and hence undermines the immutability of religious rulings. Additionally, the feminist re-reading approach enables multiplicity of voices, including women's own voices in religious interpretation, which has been a central demand of many pious Iranian women. Hence, I argue that the debate on women's rights and their access to position of authority is a process. While women initially objected to their exclusion from political leadership by emphasizing lack of consensus among the clerics and strategically publicized the most liberal clerical voices, today they demand to be part of the interpretation process. In this regard, Ayatollah Saanei is considered a significant figure in helping secure women's role in religious interpretation, and is therefore continuously lobbied and pressured by various pious women's rights groups. However, the process of establishing Iranian women's political and religious authority within the Islamic republic remains incomplete. Many pious female activists continue to refer to and publicize religious interpretations of male clerics, such as Saanei, rather than a female interpreter, since his words as a marja are acceptable to a wider audience and hence more effective given Iran's current political and social context.

It is noteworthy to also include that, while a majority of the reformist figures in modern Iran are battling out their opposing strategies of addressing women's under-representation in leadership, a third alternative (mostly non-clerical) approach has also come to light in recent years, which presents itself as the most pragmatic, and as a result is championed by many women's rights activists, both religious and secular. This latter approach is considered conciliatory between the two previous positions as it moves away from the language of sound or erroneous clerical interpretations. In an effort to solve the problem of women's inefficiencies for most positions of authority in modern Iran, particularly those that list as qualifications aspects of religious authority that have traditionally been closed to women, this approach emphasizes the administrative role of most political leadership positions. In other words, this approach argues that constitutionally required religious qualifications such as being a mujtahid, mufti, faqih, or even rijal for political leadership positions should not bar women from accessing them, since in the modern state such positions require implementation of specific laws, rulings, or responsibilities [9]. Similar to other reformist positions, this approach was sought due to extensive pressuring from various Iranian women's rights activists who viewed such limitations of religious authority as discriminatory towards women's access to politics.

\section{Conclusions}

In this work I illustrated that the recent rise in reformist Shi'i ideology regarding female authority is in a large part due to women's activism and pressuring of Iranian religious and political elites. Particularly, within the last decade we have witnessed a shift in Shi'i clerical discourse from the conventional stance that banned women's access to decision-making positions based on traditional interpretations that limited women to the private sphere. Different groups of women's demands for 
further presence in politics challenged the historical male dominance over the political sphere, as well as the religious elites who maintained such male privilege through their traditional interpretations and implementations of religious texts. Today, the clerics no longer have the comfort of passing rulings about an abstract notion of woman since they are faced with intelligent and capable women that demand reform of male-dominated rulings from within a religious framework. Today, women no longer accept that God had ordained that men should rule over women. In this regard, the religious women's movement in Iran which is often led by renowned learned women who themselves were inspired and nurtured by the Islamic regime and its revolutionary ideals, has been at the forefront of championing such changes and opening avenues for women's political representation.

A central strategy of the Iranian women's movements was to involve the religious leaders into a dialogue. Once their demands were voiced to the ulema, they strategically publicized the exchanges between women's organizations and state or religious officials in women's journals in an effort to popularize and legitimize the issue of women's access to political decision-making. This tactic was considered the first step towards reform of patriarchal interpretations, as it forced the clerics to review Islamic texts in response to women's demands, particularly since such demands were often voiced by pious women who were also devoted to the Islamic regime. Women's success in publicizing such debates and their influence over public opinion illustrates their leverage over state officials, who were forced to be responsive to women's demands for greater political representation as they depend on public legitimacy and women's vote to stay in power. By reviewing and closely analyzing the strategic interactions that have been recently taking place in women's journals or other media outlets, this work not only shed light onto the nature of women's strategizing and the regime's reactions, but also recognized two dominant categories of reformist justification for their support for women's access to leadership positions in modern times.

This paper argued that reformist rereading on this subject falls into the categories of contextual or feminist. While the contextual rereading emphasizes changes in today's context and culture as a justification for increasing women's access to positions of authority, the feminist rereading rather emphasizes correction of conventional clerical misinterpretation and patriarchy that limited women's access to politics. I argue that recognition of these subtle differences and distinction between these types of religious reform is important as each has a different implication for women and the future prospects of reform in the society. Particularly, this work examined the extent to which each of these reformist positions democratize religious interpretation, and recognized that a feminist rereading enables multiplicity of voices in religious reform as it can undermine the authenticity of many male clerics, who erred in their conventional interpretation. Indeed, although disagreement (ikhtilaf) among the ulema is permitted and even expected in Muslim jurisprudence, this feature is often problematic within the Iranian theocratic system. This is because Iran's laws are largely shaped by a small minority of conservative clerics, who take every measure to maintain their clerical monopoly over the legal system and ultimately the authority of the government. Therefore, a reformist agenda that democratizes religious interpretation, such as by granting interpretative power even to lay intellectuals, can have important impacts on the country's laws. However, I argue that although there is a demand for feminist centered re-reading and re-interpretations of religious texts, the current dominant Shi' $i$ reformism still maintains its monopoly on religious interpretation and the process of opening such spaces to women is still incomplete. This dominance undermines the possibilities for future 
democratization of religious interpretation in which various voices including non-clerical ones can be taken into account.

\section{References}

1. Mir-Hosseini, Z. Stretching the Limits: A Feminist Reading of the Shari'a in Post-Khomeini Iran. In Feminism and Islam: Legal and Literary Perspectives; Yamani, M., Allen, A., Eds.; New York University Press: New York, NY, USA, 1996; pp. 285-320.

2. Yadegar-Azadi, M. Ghezavat Zanan (Women's Judgeship). Zanan 1992, 5, 17-25.

3. Mehrizi, M. Shakhsiat va Hoquq Zan dar ISlam (Women's Rights and Characteristics in Islam); Sherkat Entesharat Elmy va Farhangy: Tehran, Iran, 2003; p. 503.

4. Mir-Hosseini, Z. Islam and Gender: The Religious Debate in Contemporary Iran; Princeton University Press: Princeton, NJ, USA, 1999; p. 305.

5. An-Naim, A.A. Toward a Cross-Cultural Approach to Defining International Standards of Human Rights: The Meaning of Cruel, Inhuman, or Degrading Punishment. In Human Rights in CrossCultural Perspectives: A Quest for Consensus; An-Naim, A.A., Ed.; University of Pennsylvania Press: Philadelphia, PA, USA, 1992; pp. 19-43.

6. Phillips, A., Ed. Feminism and Politics; Oxford University Press: New York, NY, USA, 1998; p. 471.

7. Pateman, C. The Sexual Contract; Stanford University Press: Stanford, CA, USA, 1988; p. 264.

8. Inter-Parliamentary Union. Women in National Parliaments. http://www.ipu.org/wmn-e/world.htm (accessed on 13 June 2011).

9. Kar, M. Mosharekateh Siasy Zanan: Mavane' va Emkanat (Women's Political Participation: Obstacles and Opportunities); Entesharat Roshangaran va Motale'at Zanan: Tehran, Iran, 2000; p. 173.

10. Ebadi, S.; Moaveni, A. Iran Awakening: From Prison to Peace Prize: One Woman's Struggle at the Crossroads of History; A.A. Knopf Canada: Toronto, Canada, 2006; p. 232.

11. Mir-Hosseini, Z. Sexuality, Rights and Islam: Competing Gender Discourses in Postrevolutionary Iran. In Women in Iran: From 1800 to the Islamic Republic; Beck, L., Nashat, G., Eds.; University of Illinois Press: Urbana, IL, USA, 2004; pp. 204-217.

12. Motahhari, M. Nezam-e Hoghoghe Zan dar Islam (The System of Women's Rights in Islam); Sadra Publications: Tehran, Iran, 1978; p. 332.

13. Afshar, H. Khomeini's Teachings and their Implications for Women. Fem. Rev. 1982, 12, 59-72.

14. Paidar, P. Women and the Political Process in Twentieth-Century Iran; Cambridge University Press: New York, NY, USA, 1995; p. 401.

15. Mernissi, F. The Forgotten Queens of Islam; University of Minnesota Press: Minneapolis, MN, USA, 1993; p. 229.

16. Kian-Thiebaut, A. Women's Religious Seminaries in Iran. ISIM Newsletter 2000, 6, 23.

17. Hoodfar, H. The Women's Movement in Iran: Women at the Crossroads of Secularization and Islamization; Women Living Under Muslim Laws: Grabels Cedex, France, 1999; p. 46.

18. Saidzadeh, M. Zanan dar Jame'h madani che andazeh sahm darand? (What is Women's Role in the Civil Society?); Nashr Ghatreh: Tehran, Iran, 1998. 
19. Hoodfar, H.; Sadr, S. Islamic Politics and Women's Quest for Gender Equality in Iran. Third World Q. 2010, 31, 885-903.

20. Mir-Hosseini, Z. Muslim Women's Quest for Equality: Between Islamic Law and Feminism. Crit. Inq. 2006, 32, 629-645.

21. Najmabadi, A. (Un)Veiling Feminism. Soc. Text 2000, 64, 29-45.

22. Mir-Hosseini, Z. Religious Modernists and the "Woman Question": Challenges and Complicities. In Twenty Years of Islamic Revolution: Political and Social Transition in Iran since 1979; Hooglund, E., Ed.; Syracuse University Press: New York, NY, USA, 2002; pp. 74-95.

23. Hoodfar, H.; Sadr, S. Can Women Act as Agents for the Democratization of Theocracy in Iran? United Nations Research Institute for Social Development (UNRISD): Geneva, Switzerland, 2009; pp. 3-37.

24. Spellberg, D.A. Politics, Gender, and the Islamic Past: The Legacy of Aisha bint Abi Bakr; Columbia University Press: New York, NY, USA, 1994; p. 243.

25. Shariati, A. Fatima is Fatima; Shariati Foundation: Tehran, Iran, 1981; p. 226.

26. Mernissi, F. The Veil and the Male Elite: A Feminist Interpretation of Women's Rights in Islam; Addison-Wesley Publications: Reading, MA, USA, 1991; p. 228.

27. Taleghani, A. Tasvib bedoone Tasrih: Morrory bar Tasvib Asl Marboot be Sharayet Ra'is Jomhury (Adoption without Clarification: A Review of the Adoption of the Constitutional Requirements for Presidency). Payam-e Hajar 1997, 227, 5-7.

28. Hoodfar, H.; Tajali, M. Electoral Politics: Making Quotas Work for Women; Women Living Under Muslim Laws (WLUML): London, UK, 2011; p. 238.

29. Taleghani, A. Chera Kandidaye Riasat Jomhury Shodam? (Why did I Become a Presidential Candidate?). Payam-e Hajar 1997, 227, 2-4.

30. Samii, A.W. Iran's Guardians Council as an Obstacle to Democracy. Middle East J. 2001, 55, 643-662.

31. Esfandiari, G. Iran: Women Call for Rights Ahead of Presidential Poll. Available online: http://www.payvand.com/news/05/jun/1092.html (accessed on 26 June 2011).

32. Haeri, S. Iran's Invisible Candidates. Harvard Divinity Bulletin 2006, 34.

33. Amnesty International. Iran: Ensure Free Presidential Election. Available online: http://www.amnesty.org/en/library/asset/MDE13/046/2009/en/25d062b9-2643-4a8e-908ad72929557665/mde130462009en.html (accessed on 30 April 2011).

34. Alef News. Shura-e Negahban: Zanan Mitavanand Candidatoury Riasat Jomhoury Shavand (Council of Guardians: Woman can be Presidential Hopefuls). Updated April 11, 2009. Available online: http://alef.ir/1388/content/view/43462/ (accessed on 2 August 2011).

35. Press TV. Iran 'does not rule out Female Presidency'. Updated April 11, 2009. Available online: http://edition.presstv.ir/detail/91141.html (accessed on 2 August 2011).

36. Paidar, P. Gender of Democracy: The Encounter between Feminism and Reformism in Contemporary Iran. In Democracy, Governance and Human Rights Programme Paper Number 6; United Nations Research Institute for Social Development: Geneva, Switzerland, 2001; p. 56.

37. Shahrokni, N. All the President's Women. Middle East Rep. 2009, 253. Available online: http://www.merip.org/mer/mer253/all-presidents-women (accessed on 22 April 2011). 
38. Omidy, S. Khatami: Elzami barayeh Entekhabe yek Zan be onvaneh Vazir vojood nadard (Khatami: 'Selection of a Female Minister is not Necessary'). Zanan 2001, 79, 10-11.

39. Voice of America. Iranian Clerics Question Nomination of Women Ministers. Available online: http://iranelection2009.com/archive/2009/08/25/iranian-clerics-question-nomination-womenministers-voa (accessed on 30 April 2011).

40. Payvand News. Women MP, Fatemeh Alia, nominated as Iran's Education Minister. Available online: http://www.payvand.com/news/09/sep/1069.html (accessed on 22 April 2011).

41. Hoodfar, H. Women, Religion, and Electoral Politics in the Islamic Republic. Paper presented at Center for Middle East Studies, University of California, Berkeley, CA, USA, 6 April 2010.

42. Lutfi, M. The Women's Mufti: Interview with Grand Ayatollah Yousef Saanei. Available online: http://www.aawsat.com/english/news.asp?section=3\&id=8554 (accessed on 30 April 2011).

43. Taleghani, A. Aya Zan mitavanad Ra'is Jomhur shavad? (Can a Woman become President?). Payam-e Hajar 1997, 227, 8-15.

44. Personal interview with Mrs. Touran Valimorad Secretary of Coalition of Islamic Women, July 2011.

45. Personal interview with Maryam Behroozi, Zeinab Society’s director, July 2011.

(C) 2011 by the authors; licensee MDPI, Basel, Switzerland. This article is an open access article distributed under the terms and conditions of the Creative Commons Attribution license (http://creativecommons.org/licenses/by/3.0/). 